\title{
Downregulation of RSK2 influences the biological activities of human osteosarcoma cells through inactivating AKT/mTOR signaling pathways
}

\author{
QUANHE QIU ${ }^{1}$, JING JIANG ${ }^{2}$, LIANGBO LIN ${ }^{1}$, SI CHENG $^{1}$, DAQI XIN ${ }^{3}$, \\ WEI JIANG ${ }^{1}$, JIELIANG SHEN ${ }^{1}$ and ZHENMING HU ${ }^{1}$
}

${ }^{1}$ Department of Orthopaedic Surgery, The First Affiliated Hospital of Chongqing Medical University, Chongqing 400016; ${ }^{2}$ Department of Clinical Laboratory, The Third Affiliated Hospital of Nanchang University, Nanchang, Jiangxi 330008; ${ }^{3}$ Department of Orthopaedic Surgery, The Second Affiliated Hospital of Neimenggu Medical University, Huhehaote, Neimeng 010030, P.R. China

Received January 17, 2016; Accepted February 18, 2016

DOI: 10.3892/ijo.2016.3481

\begin{abstract}
RSK2 (90 kDa ribosomal S6 kinase) is a downstream effector of the Ras/ERK (extracellular signal-regulated kinase) signaling pathway that has major functions in cell biological activities, including regulating nuclear signaling, cell cycle progression, cell proliferation, cell growth, protein synthesis, cell migration and cell survival, and is expressed in most types of human malignant tumors, including lung cancer, prostate and breast tumors, skin cancer and osteosarcomas (OS). RSK2 was found to be essential for osteosarcoma formation. To investigate whether RSK2 is expressed at high levels in human osteosarcome tissues and whether its expression is correlated with the aggressive biological behavior of osteosarcoma cell line (OCLs), we assessed the association between RSK2 expression and OS cell progression, as well as the effects of RSK2 inhibition on the biological activities of osteosarcoma cells. We performed immunohistochemistry to analyze the expression of RSK2 in specimens from 30 humans with osteosarcoma, and 15 normal tissues. RSK2 gene expression levels in 30 specimens with osteosarcoma were significantly higher than those of normal tissues. We performed RNA interference on three OCLs to evaluate cell apoptosis, cell growth, cell proliferation, cell motility, chemosensitivity and oncogenicity. After transfection with RSK2 shRNA, increased cell apoptosis, cell growth inhibition, cell cycle progression, weaker cell proliferation, cell migration and weaker tumor formation were observed in all OCLs. These results suggested that RSK2 expression may mediate the biological activities of OS cells
\end{abstract}

Correspondence to: Professor Zhen-Ming Hu, Department of Orthopaedic Surgery, The First Affiliated Hospital of Chongqing Medical University, 1 Youyi Rd., Chongqing 400016, P.R. China

E-mail: spinecenter_hu@163.com

Key words: Akt PKB, mammalian target of rapamycin, osteosarcoma, ribosomal S6 kinase, short hairpin RNA, signal transduction and RSK2 may be an effective therapeutic target for the treatment of osteosarcomas. The AKT/mTOR, MAPK/ERK/c-Fos and $\mathrm{Bcl} 2 / \mathrm{Bax}$ pathways were analysed to clarify the mechanisms involved.

\section{Introduction}

Osteosarcoma is the most common malignant bone tumor with a 5-year survival rate $<70 \%$ (1). Most patients present with lung metastatic lesions $(2,3)$ or bone metastatic lesions and are incurable. Hence, a better understanding of the biological processes underlying osteosarcoma cell motility, survival, proliferation, invation and metastasis is needed to improve patient survival. New gene targeting therapy is a strong hope for osteosarcoma individual tumors.

The 90-kDa ribosomal S6 kinase (RSK) family, first purified in 1985 (4), is activated by the MAPK (mitogen-activated protein kinase) family members ERK1/2 (extracellular signalregulated kinase 1/2) in response to growth factors, phorbol esters and other agonists (5-7). The human RSK family contains four isoforms (RSK1-4) (8). RSKs are characterised by the existence of two kinase domains that come into close proximity following activating phosphorylation events and connected by a regulatory linker region. Their downstream substrates include a number of cytoplasmic and nuclear targets (CREB, c-Fos, c-Jun, TSC2 and filamin A) (8) that explain their involvement in diverse cellular processes, such as cell proliferation and survival. Increased expression of RSKs was shown in breast (9) and prostate cancer (10), and RSK2 activity has been linked to cell transformation $(11,12)$. RSKs have been shown to phosphorylate filamin A (13), glycogen synthase kinase-3 (14-16) and p27Kip (17), and also Bad (18), c-Fos (19) and estrogen receptor (20). Evidence from human and mouse has identified an important role for RSK2 in osteoblast differentiation and function through phosphorylation of activating transcription factor-4 (21) and in stimulation of white adipose tissue mass via an unknown mechanism (22).

In this study, immunohistochemical staining revealed that RSK2 was overexpressed in osteosarcoma samples compared 
with normal matched tissues. Then we performed an shRNA in three human osteosarcoma cell lines (MG-63, U2-OS, 143B) and demonstrated that RSK2 silencing increased apoptosis and chemosensitivity, reduced proliferation, migration and oncogenesis. This could potentially be explained by activation of $\mathrm{Bax}$ and inhibition of $\mathrm{Bcl} 2$, c-Fos phosphorylation and AKT, mTOR phosphorylation, a series of cell factors that are associated with cell viability and apoptosis. Thus, in osteosarcomas, our results suggest that knockdown of RSK2 increased cell apoptosis, enhanced cell chemosensitivity, inhibits proliferation and migration, and weakened tumor formation, RSK 2 might be a potential target of biotherapy to osteosarcomas.

\section{Materials and methods}

Reagents. Fetal bovine serum (FBS) and DMEM were purchased from Gibco (San Francisco, CA, USA). Primary antibodies: rabbit anti-human RSK2 was from Bioworld (USA). Rabbit anti-human total c-Fos, rabbit anti-human total AKT, rabbit anti-human total mTOR, and phosphorylated ERK, phosphorylated AKT, phosphorylated mTOR were from Cell Signaling Technology (Boston, MA, USA). Rabbit antihuman Bax, Bcl2, caspase-3, rabbit anti-human Ki67 nuclear antigen, mouse anti-human PCNA, mouse anti-human $\beta$-actin and mouse anti-human glyceraldehydes-3-phosphate dehydrogenase (GAPDH) were from Santa Cruz Biotechnology (San Francisco, CA, USA). Horseradish peroxidase-conjugated goat anti-rabbit and goat anti-mouse secondary antibodies were from Zhong Shan Golden Bridge Biotechnology (Beijing, China).

shRNA. The RSK2 shRNA were designed and synthesized by Genechem Co. Ltd. (Shanghai, China) and the sequences targeting RSK2 were 5'-TGCCACAATACCAACTAAA-3'. A non-specific scrambled shRNA with a sequence of 5'-TTCTC CGAACGTGTCACGT-3' was used as a negative control. Transfection with shRNA was accomplished using cationic liposome (Lipofectamine 2000; Invitrogen, Carlsbad, CA, USA), according to the manufacturer's instructions.

Specimen collection. Specimens were collected from 30 patients with osteosarcomas by excisional or needle biopsy at initial medical examinations in Cancer Hospital of Guizhou Medical University between October 2012 and September 2015. All tumor biopsies were collected by excisional biopsy or needle core biopsy at the time of initial diagnosis, before preoperative chemotherapy or radiotherapy, with informed consent from patients/guardians and approval from the relevant institutional Research Ethics Committees. All specimens were confirmed by histopathological examination. The patients were divided into IA, IB, IIA, IIB and III grade according to the GTM staging (data not shown).

Immunohistochemistry (IHC). Antigen retrieval on the deparaffinized sections was performed by immersing the specimens in $0.1 \mathrm{M}$ citrate buffer ( $\mathrm{pH}$ 6.0), boiling the sections in the microwave for $10 \mathrm{~min}$, and then allowing the sections to cool to room temperature. Endogenous peroxidase activity was blocked by immersing the sections in methanol containing $3 \%$ hydrogen peroxide for $10 \mathrm{~min}$. Then the sections were blocked in FCS for $10 \mathrm{~min}$ at room temperature. The sections were incubated overnight at $4^{\circ} \mathrm{C}$ with the RSK2 antibody (1:50), washed in phosphate-buffered saline (PBS) three times for 5 min each. The sections were incubated with the secondary antibody at $37^{\circ} \mathrm{C}$ for $30 \mathrm{~min}$, washed in phosphate-buffered saline (PBS) three times for 5 min each. Streptavidin conjugated peroxidase was added for $10 \mathrm{~min}$ at room temperature. Diamino-benzidine substrate was added for $5 \mathrm{~min}$ for visualizing. Immunohistochemical staining of RSK2 was calculated as both percentage of positive cells and color intensity. The percentage of the positivity of staining was graded as 0 (negative), $1(<10 \%), 2(10-50 \%)$ and $3(>50 \%)$. The intensity of staining was scored as 0 (absent), 1 (light yellow), 2 (yellowish brown) and 3 (brown). The staining index (SI) was used for assessing the expression of RSK2. SI, proportion score $\mathrm{x}$ intensity score: $0-2$ was categorized as negative (1-2 as low expression), 3-9 was positive (3-4 as moderate expression, 6 and 9 as high expression).

Cell lines and cell culture. Three human OS cell lines (MG63, 143B and U2OS) were recently purchased from Shanghai Life Academy of Sciences cell library (Shanghai, China). All cells were cultured and maintained in Dulbecco's modified Eagle's medium (DMEM; Hyclone, Logan, UT, USA) supplemented with $10 \%$ heat-inactivated fetal bovine serum (FBS; Hyclone) and antibiotics (100 IU/ml penicillin and $100 \mathrm{mg} / \mathrm{ml}$ streptomycin; Hyclone) in a humidified incubator with $5 \% \mathrm{CO}_{2}$ at $37^{\circ} \mathrm{C}$.

Knockdown of RSK2 in OS cells. OS cells were seeded with DMEM supplemented with $10 \%$ FBS in 96-well plates (Costar Corning Inc., NY, USA) at $1-2 \times 10^{5}$ cells/well or 6 -well plates (Costar Corning Inc.) at $1-2 \times 10^{6}$ cells/well and incubated overnight in an incubator with $5 \% \mathrm{CO}_{2}$ at $37^{\circ} \mathrm{C}$. RSK 2 shRNA and scrambled shRNA were diluted in deionized distilled water (DDW) according to the manufacturer's instructions. Diluted shRNAs were complexed in $0.5 \mathrm{ml}$ of cationic liposome dissolved in $1 \mathrm{ml}$ DDW for 96 -well plates $(10 \mathrm{ml}$ of cationic liposome for 6-well plates) and were incubated at room temperature for $20 \mathrm{~min}$. Then, $0.5 \mathrm{ml}$ of shRNA/liposome complexes were added to each well in 96 -well plates $(10 \mathrm{ml}$ for 6 -well plates), and cells were incubated in an incubator with $5 \% \mathrm{CO}_{2}$ at $37^{\circ} \mathrm{C}$.

Measurement of cell proliferation. The change of cell proliferation was observed with Cell Counting Kit-8 (CCK-8) assay. All cells were seeded in 96-well cell culture cluster plates at a density of $2 \times 10^{4}$ cells/well in $100 \mu \mathrm{l}$ culture after transfecting RSK2-shRNA and control shRNA. Then, $10 \mu \mathrm{l} \mathrm{CCK-8}$ (Beyotime Institute of Biotechnology, Beijing, China) reagents were added to each well for 2 -h incubation at $37^{\circ} \mathrm{C}$ according to the manufacturer's instructions after 24, 48, 72, 96 and $120 \mathrm{~h}$. The absorbance value was read at $450 \mathrm{~nm}$ using an enzyme-labeled instrument. The experiments were repeated three times.

Flow cytometry analysis (FCM) of cell cycle distributions. OS cells were transfected with RSK2-shRNA and scramble shRNA, then collected at $48 \mathrm{~h}$ after transfection in suspension 
to each tube. For cell cycle analysis, starvation-refeeding model was used. To begin with, OS cells were incubated without fetal bovine serum for $48 \mathrm{~h}$ to synchronize cells, then changed into complete medium and collected cells. Furthermore, cells were fixed in $70 \%$ ethanol for $\geq 24 \mathrm{~h}$ at $-20^{\circ} \mathrm{C}$. Subsequently, the cells incubated with $1 \mathrm{mg} / \mathrm{ml}$ RNase (Sigma, St. Louis, MO, USA) for $30 \mathrm{~min}$ at $37^{\circ} \mathrm{C}$ in PBS, stained with $50 \mu \mathrm{g} / \mathrm{ml}$ propidium iodide (Sigma) in PBS-Triton X-100 for an additional $20 \mathrm{~min}$ at $4^{\circ} \mathrm{C}$, and analyzed using a Becton-Dickinson flow cytometer BD FACScan (San Jose, CA, USA) as well as CellQuest acquisition and analysis programs. For cell apoptosis analysis, OS cells were transfected with RSK2-shRNA and control shRNA, then the above cells were collected in suspension to each tube and $60 \mu 1 \mathrm{Muse}^{\mathrm{TM}}$ Annexin V and Dead Cell Reagent (part no. 4700-1485, 100 tests/bottle) was added, incubating for $20 \mathrm{~min}$. The apoptosis assay was completed by flow cytometer evaluation (BD Bioscience, Franklin Lakes, NJ, USA).

Cell migration assay. The Transwell chambers (Corning Inc.) were used to analyse the migration of OS cells. The cells $\left(2 \times 10^{5}\right)$ were seeded in the upper of the $8-\mu \mathrm{m}$ pore size Transwell chambers in $0.6 \mathrm{ml}$ DMEM without serum and incubated in 6-well-plates with $2 \mathrm{ml} 10 \%$ FBS supplemented DMEM. Non-migrated cells were removed by cotton swab after incubated for $24 \mathrm{~h}$. The cells were washed twice with phosphate-buffered solution (PBS) and fixed with 4\% paraformaldehyde in PBS (pH 7.4) for $30 \mathrm{~min}$ at $4^{\circ} \mathrm{C}$ and stained with $100 \mathrm{ng} / \mathrm{ml}$ crystal violet for $10 \mathrm{~min}$ at room temperature. Cells were washed twice with PBS and examined by a fluorescence microscope.

Semi-quantitative RT-PCR. Total RNA in cells was extracted using RNAiso Plus (Invitrogen). The concentration of these RNA samples was then measured using spectrophotometer at 260 and $280 \mathrm{~nm}$ (A260/280) and the RNA samples were reverse-transcribed into cDNA using the Primescript RT reagent kit (Takara Biotechnology, Dalian, China). The primer sequence for RSK2 was 5'-GGGACCAACTGCCACA ATAC-3' (forward) and 5'-TGACTGATTACGGTTCAAA GCA-3' (reverse), and for GAPDH, was 5'-CTTTGGTATCGT GGAAGGACTC-3' (forward) and reverse 5'-GTAGAGGCA GGGATGATGTTCT-3. Amplification conditions were as follows: $95^{\circ} \mathrm{C}$ for $30 \mathrm{sec}$, followed by 40 cycles at $95^{\circ} \mathrm{C}$ for $15 \mathrm{sec}$, and $60^{\circ} \mathrm{C}$ for $45 \mathrm{sec}$ in a final volume of $25 \mu \mathrm{l}$ containing 2x PCR Mi x $12.5 \mu 1,20 \mu \mathrm{mol}$ specific forward and reverse primers $1.0 \mu \mathrm{l}, \mathrm{ddH}_{2} \mathrm{O} 9.5$ and $1 \mu \mathrm{l}$ cDNA as a template. Products were electrophoresed on a $2 \%$ agarose gel, and densitometric analysis of DNA bands was tested by Quantity One 4.6 computer software (Bio-Rad, Hercules, CA, USA).

Western blotting. Cells were treated with shRNA in 100-mm cell culture dishes (Costar Corning Inc.). Cells were harvested at 24,48 , and $72 \mathrm{~h}$ after transfection with shRNA. Cells were washed twice ice-cold phosphate buffer saline (PBS, pH 7.4; Sigma-Aldrich) and lysed with $100 \mu 1$ lysis buffer (Beyotime Institute of Biotechnology) containing phosphatase inhibitors, proteinase inhibitor and PMSF. The protein concentration of each lysate was determined by Bradford protein assay using bovine serum albumin (Beyotime Institute of Biotechnology) and were denatured with SDS-PAGE loading buffer. Proteins
(30 mg for each sample) were subjected to SDS-PAGE using $10 \%$ polyacrylamide gels (Beyotime Institute of Biotechnology) and electro-transferred into polyvinylidene difluoride membrane (PVDF, 0.45). Membranes were blotted with 5\% BSA (Beyotime Institute of Biotechnology) or $5 \%$ skimmed milk powder in PBST for $2 \mathrm{~h}$ at room temperature. Membranes were incubated overnight at $4^{\circ} \mathrm{C}$ with primary antibodies against $\beta$-actin (ABM-0001, Zoonbio, Nanjing, China) and RSK2 (Bioworld, USA) at a dilution of 1:1,000 in antibody dilution solution. Membranes were washed 3 times for 10 min each with Tween-PBS and incubated with goat antirabbit or mouse horseradish peroxidase conjugate IgG Abgent (San Diego, CA, USA) at a dilution of 1:3,000 in Tween-PBS. The Fusion computer software (Vilber Lourmat, French) was used for visualization.

Xenograft tumor model. In this study, the male nude mice (4 weeks) were purchased from the experimental animal center of Chongqing Medical University. All the mouse experiments were approved by the Ethics Committee of Chongqing Medical University. The OS cells were injected subcutaneously into the nude mice at a density of $5 \times 10^{6}$ cells per $100 \mu \mathrm{l}$ PBS. Tumor volume was measure at $7,14,21,28$ days after injection. Mice were sacrificed on day 28, the xenograft tumors were dissected and embedded in paraffin for HE staining and IHC as described above.

Proliferation index in xenograft tumors. IHC staining for the expression of Ki67 and PCNA (proliferating cell nuclear antigen) xenograft tumor tissues were carried out. The proliferation index (Ki-67 and PCNA index) was measured (the percentage of positive cells from five randomly fields under a light microscopy at x400 magnification).

Chemosensitivity. The change of cell chemosensitivity was observed with a CCK- 8 colorimeter. Cells were divided into two groups (pre-transfection and post-transfection). All cells were seeded onto 96-well plates at a density of 2,000 cells/ well, cisplatin and doxorubicin with different concentrations and $10 \mu \mathrm{lCCK}-8$ were added to each well. The absorbance value was read at $450 \mathrm{~nm}$ using an enzyme-labeled instrument.

Statistical analysis. Data were expressed as the mean \pm standard deviation. Student's t-test, one-way ANOVA or Chi-square test followed by the Tukey post-hoc test for data with multiple comparisons was performed using commercial statistical software (SPSS Inc., Chicago, IL, USA) to determine significant differences between groups, and P-values at $<0.05$ were considered statistically significant.

\section{Results}

Overexpression of RSK2 gene in human specimens. The expression levels of RSK2 gene in osteosarcomas and normal bone tissues were comparatively analyzed using IHC. The expression of RSK2 (not shown) in osteosarcomas was significantly higher than normal bone tissues. The positive rate was 86.67 and $26.67 \%$ respectively, the difference was statistically significant $(\mathrm{P}<0.01)$ (Table I and Fig. 1). 

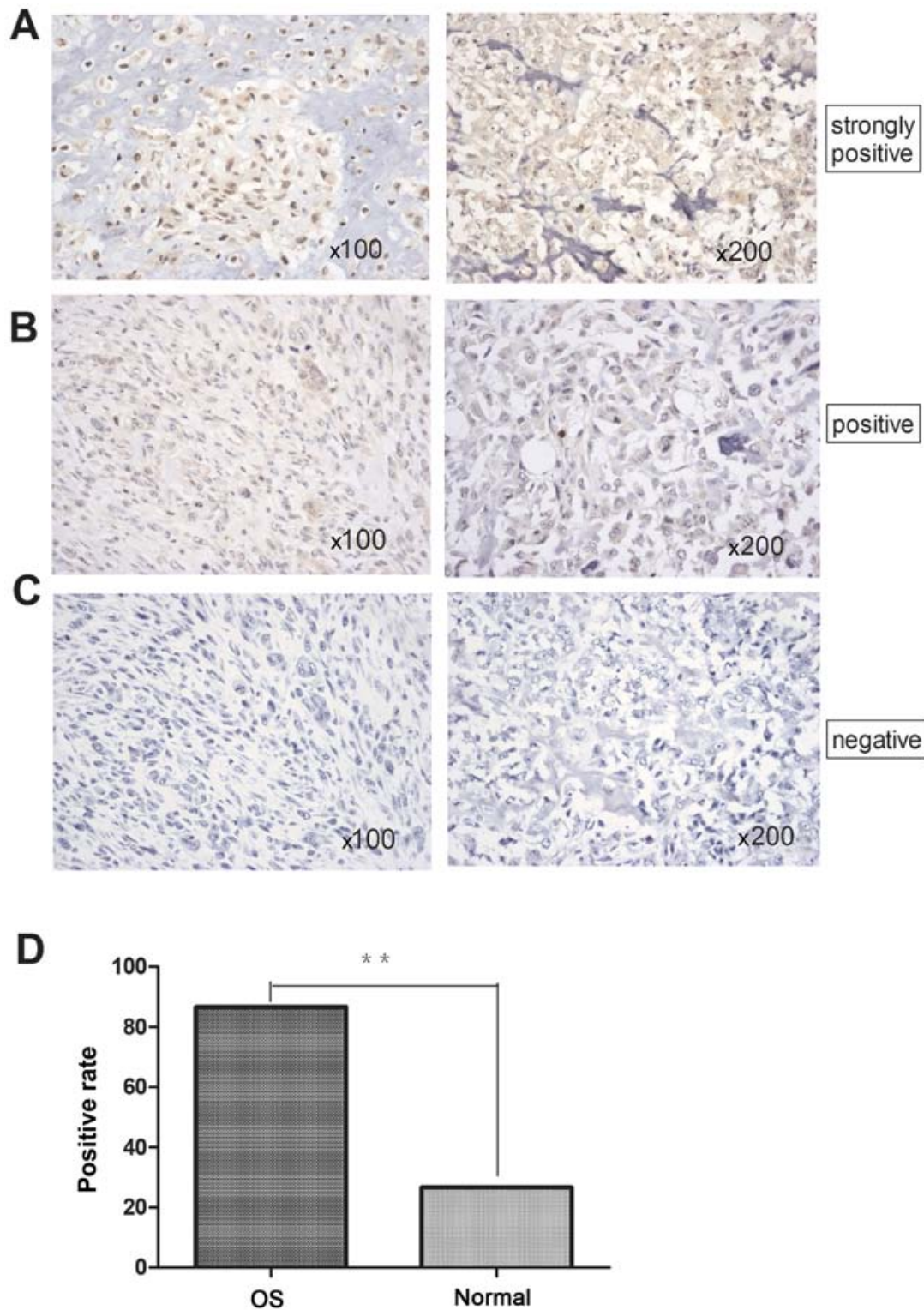

Figure 1. Expression of RSK2 protein in osteosarcomas. (A-C) Protein expression of RSK2 collected in 30 patients with osteosarcomas were analysed using immunohistochemical staining (IHC). The RSK2 was mainly located in the cell nucleus and endochylema. The strongly positive cells are brown, positive cells are brown-yellow, and the negative blue. (D) Positive rate of RSK2 in osteosarcomas and normal tissues. Each bar represents the positive rate of RSK2 in osteosarcomas and normal tissues respectively. ${ }^{* *} \mathrm{P}<0.01$ for OS vs. the normal bone tissues (Chi-square tests).

Table I. Expression of RSK2 protein in osteosarcomas and normal tissues.

\begin{tabular}{lccc}
\hline & Positive & Negative & Total \\
\hline OS & 26 & 4 & 30 \\
Normal & 4 & 11 & 15 \\
Total & 30 & 15 & 45 \\
\hline
\end{tabular}

The expression levels of RSK2 protein in osteosarcomas (OS) and normal bone tissues were comparatively analyzed using IHC. The percentage of the positivity of staining was graded as 0 (negative), $1(<10 \%), 2(10-50 \%)$ and $3(>50 \%)$. The intensity of staining was scored as 0 (absent), 1 (light yellow), 2 (yellowish brown) and 3 (brown). The staining index (SI) was used for assessing the expression of RSK2. SI, proportion score $\mathrm{x}$ intensity score: $0-2$ was categorized as negative (1-2 as low expression), 3-9 was categorized as positive (3-4 as moderate expression, 6 and 9 as high expression).
Knockdown of RSK2 in OS cell lines. To verify the transfection efficiency of the shRNA, RSK2 mRNA expression was measured at $48 \mathrm{~h}$ after transfection (Fig. 2). RSK2 mRNA expression was significantly decreased after transfection with shRNA, while scramble shRNA had only negligible effects on RSK2 expression. Western blot analysis confirmed that RSK2 protein was significantly down regulated in all OS cells at $48 \mathrm{~h}$ after transfection with RSK2 shRNA (Fig. 3); scrambled shRNA did not affect RSK2 protein expression in any cell lines. According to the results above, RSK2 shRNA could effectively knock down the RSK2 gene in mRNA level and the protein level.

Influence of RSK2 inhibition on cell apoptosis and cell cycle progression. At $48 \mathrm{~h}$ after transfection with shRNA, Annexin V-PI staining was performed to detect apoptotic 


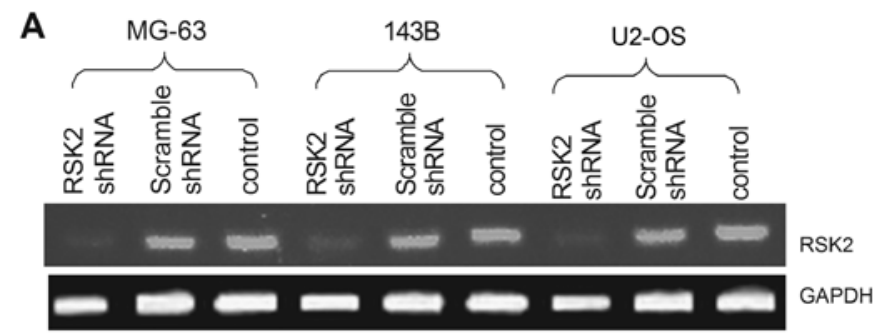

B

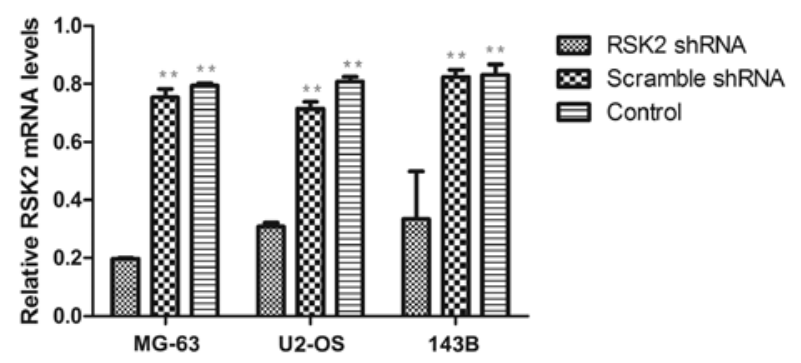

Figure 2. Expression of RSK2 mRNA in OS cell lines after transfected with RSK2 shRNA. (A) RSK2 mRNA expression in OS cell lines was evaluated by semi-quantitative RT-PCR at $48 \mathrm{~h}$ after transfection with RSK2 shRNA. The expression of RSK2 mRNA in all three OS cell lines was decreased significantly with respect to RSK2 shRNA compared to control group or scrambled shRNA. (B) The relative density of RSK2 mRNA is expressed as the ratio (RSK2/GAPDH). Data represent the mean \pm SD of three independent experiments. ${ }^{* *} \mathrm{P} \leq 0.01$ versus control.

A

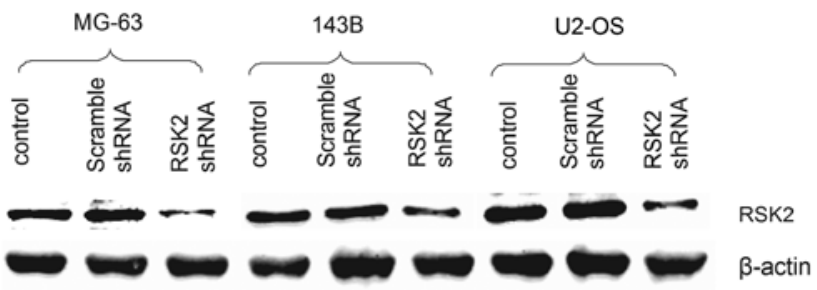

B

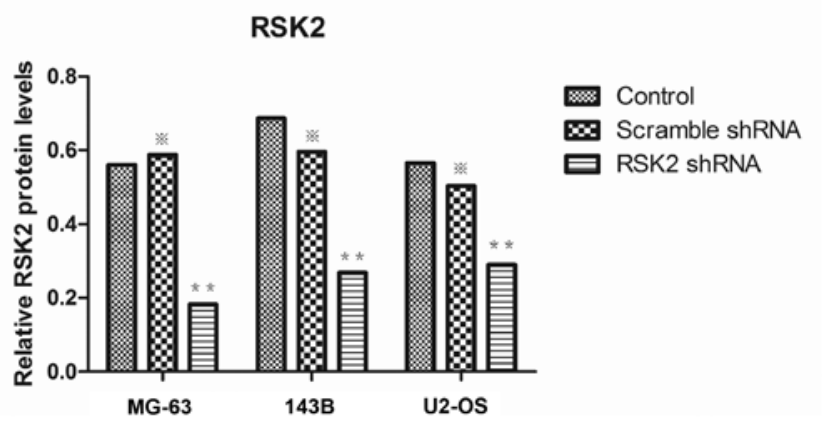

Figure 3. Expression of RSK2 protein in OS cell lines after transfection with shRNA. (A) RSK2 protein expression in OS cell lines was evaluated by western blotting at $48 \mathrm{~h}$ after transfection with scrambled and RSK2 shRNA. (B) The relative density of RSK2 protein are expressed as the ratio (RSK2/ $\beta$-actin). Data represent the mean $\pm \mathrm{SD}$ of three independent experiments. ${ }^{*} \mathrm{P} \leq 0.05,{ }^{* *} \mathrm{P} \leq 0.01$ versus control.

cells and cell cycle progression. After transfection with RSK2 shRNA, apoptosis was significantly increased in all OS cells compared to cells without transfection (Fig. 4). The cell cycle analysis showed that cells were arrested in the
Table II. The 50\% inhibitory concentrations of cisplatin and doxobubicin in OS cell lines.

\begin{tabular}{llllll}
\hline & \multicolumn{2}{c}{ Cisplatin $(\mathrm{ng} / \mu \mathrm{l})$} & & \multicolumn{2}{c}{ Doxorubicin $(\mathrm{ng} / \mu \mathrm{l})$} \\
\cline { 2 - 3 } Cell lines & Pre $^{\mathrm{a}}$ & Post $^{\mathrm{b}}$ & & Pre $^{\mathrm{a}}$ & Post $^{\mathrm{b}}$ \\
\hline MG-63 & 4.66 & 3.4 & & 2.08 & 1.11 \\
143B & 4.71 & 3.91 & & 2.13 & 1.04 \\
U2-OS & 4.83 & 3.79 & & 2.05 & 1.10 \\
\hline
\end{tabular}

The $50 \%$ inhibitory concentration was detected with the CCK-8 colorimeter at $450 \mathrm{~nm}$ using an enzyme-labeled instrument. ${ }^{\text {aPre, }}$ no treatment. ${ }^{\text {bPost, at }} 48 \mathrm{~h}$ after transfection with RSK2 shRNA.

G1/S phase, while blockage was not observed in the untransfected OS cells.

Influence of RSK2 inhibition on cell proliferation. At $48 \mathrm{~h}$ after transfection with shRNA, cell viability was evaluated (Fig. 5). After transfection with RSK2 shRNA, the viability of all OS cells was significantly decreased as compared to that of the control. In contrast, cells transfected with scrambled shRNA exhibited no changes in cell viability as compared to the control. Of the OS cell lines, three exhibited no difference in cell viability compared to each other.

Influence of RSK2 inhibition on cell chemosensitivity. The sensitivity of OS cells to cisplatin and doxorubicin after transfection with shRNA were evaluated. After transfection with RSK2 shRNA, the $\mathrm{IC}_{50} \mathrm{~S}$ of cisplatin and doxorubicin decreased in all three cell lines. In contrast, the $\mathrm{IC}_{50} \mathrm{~s}$ of these drugs were not significantly affected by transfection with scrambled shRNA in any cell line (data not shown) (Table II).

Influence of RSK2 knockdown on migration activity. The migration activity of OS cells after transfection with RSK 2 shRNA at $48 \mathrm{~h}$ was weaker than that of control. In addition, the three cell lines showed no difference by naked eye and the differences were not significant (Fig. 6).

Influence of RSK2 inhibition on protein expression. At $48 \mathrm{~h}$ after transfection with RSK2 shRNA, expression of related proteins were altered in OS cell lines as compared to control and scrambled shRNA-transfected cells. In addition, RSK2 knockdown weakened the expression of p-AKT, and p-mTOR (Fig. 7). Knockdown of RSK2 also weakened the expression of Bcl2, enhanced the expression of Bax, but did not influence the expression of caspase-3 (Fig. 8). In addition, inhibition of RSK2 influenced the expression of c-Fos, but could not reversely stimulate the expression of p-ERK (Fig. 9).

Influence of RSK2 knockdown on xenograft tumors. The activity of OS cells to produce xenograft tumor was tested in nude mice. The cells after transfection with RSK2 shRNA were considered to produce less xenografted tumors than that of the control group. In addition, the tumors of the 
A
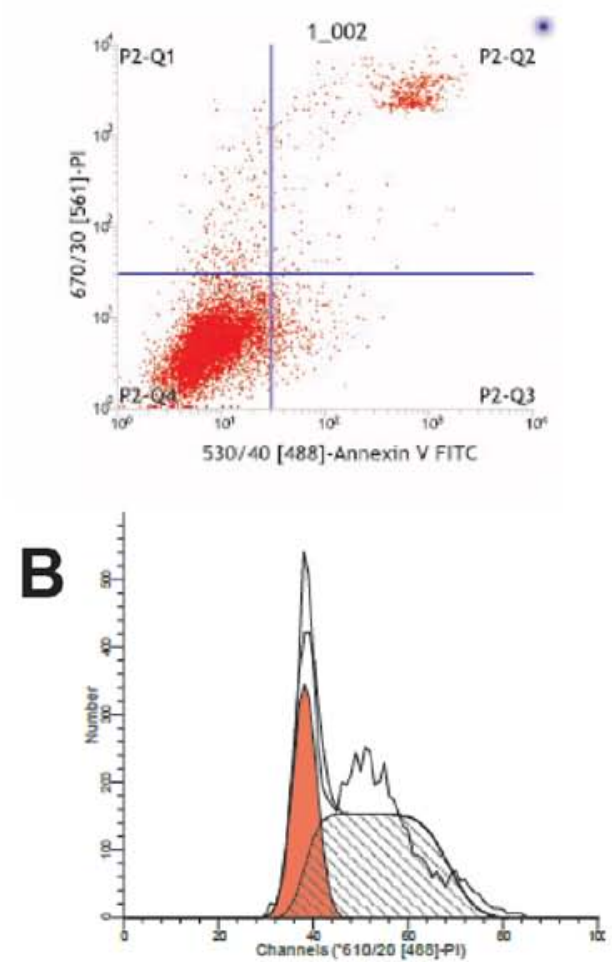

RSK2 shRNA
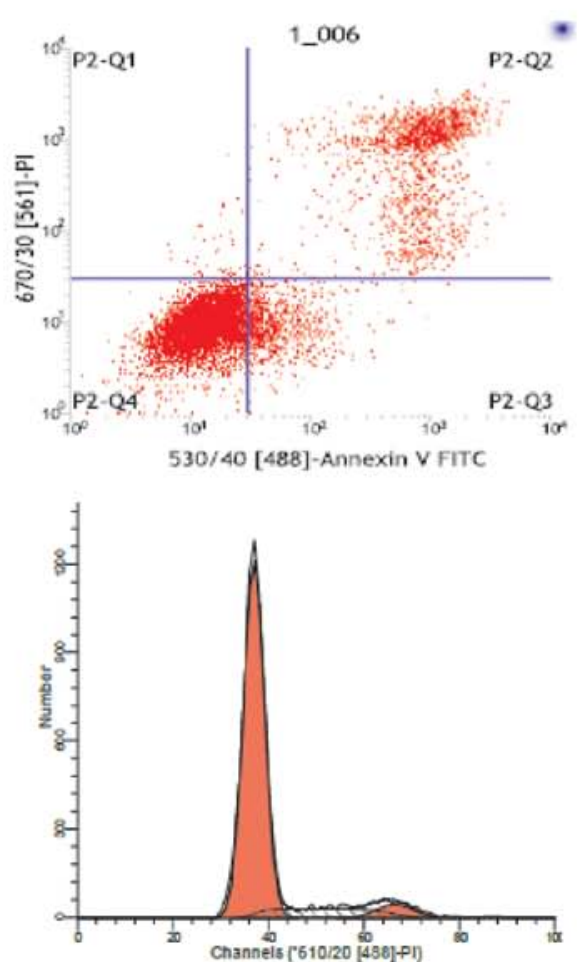

C

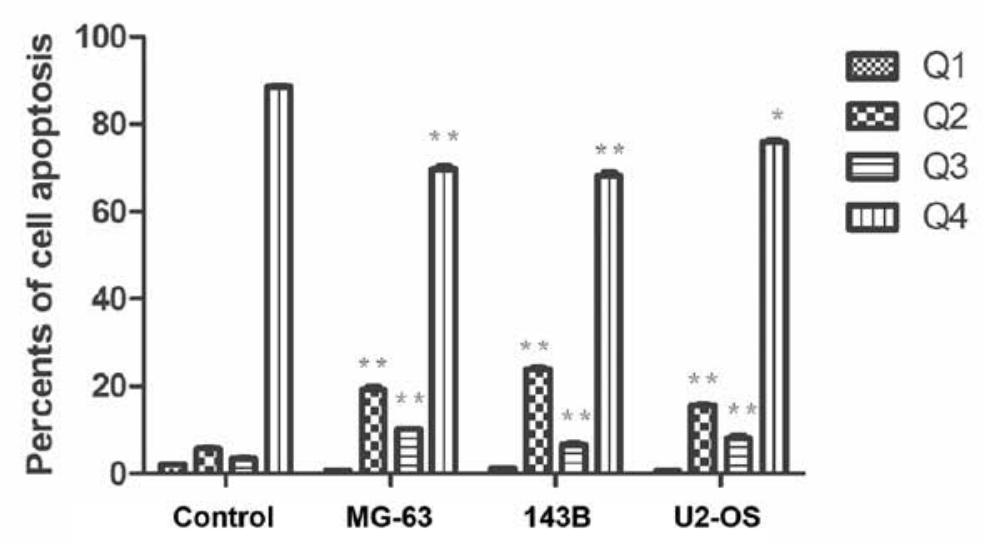

D

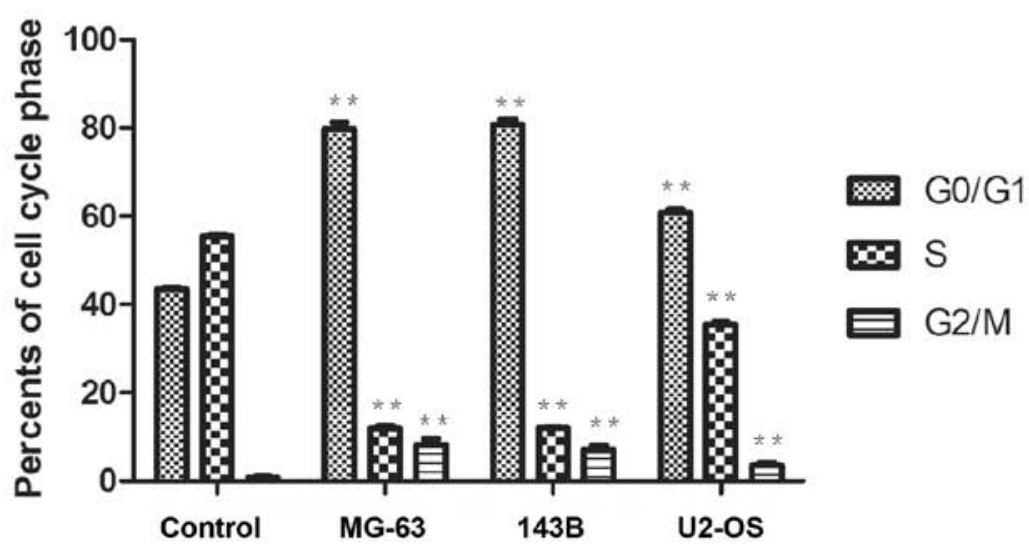

Figure 4. OS cell apoptosis and cell cycle were analysised by Annexin V-PI staining. (A) Representative images showing gross increased counts of apoptotic cell in three OS cell lines. (B) Representative images showing cell cycle arrest induced by RSK2 shRNA at $48 \mathrm{~h}$ in three OS cell lines. (C) The percentage of OS cells in 4 quadrants respectively. Q1, dead cells, Q2, late apoptotic cells, Q3, early apoptotic cells, and Q4, live cells. The values represent the means \pm SD of three experiments performed in triplicate. ${ }^{*} \mathrm{P} \leq 0.05,{ }^{* *} \mathrm{P} \leq 0.01$, versus control as determined by the Student's t-test. (D) The percentage of cell cycle phase. The cells were fixed by $70 \%$ ethylalcohol before detection. The values represent the means $\pm \mathrm{SD}$ of three experiments performed in triplicate. ${ }^{*} \mathrm{P} \leq 0.05,{ }^{* *} \mathrm{P} \leq 0.01$ versus control, as determined by the Student's t-test. 


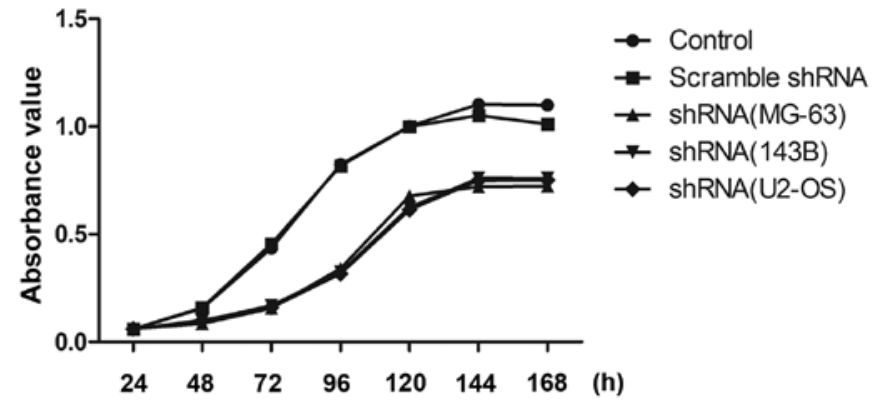

Figure 5. The effects of RSK2 shRNA on the proliferation of OS cells. The OS cell lines were treated with RSK2 shRNA. The cell proliferation was assessed at 24, 48, 72, 96, 120, 144 and $168 \mathrm{~h}$ after transfection. control group were smaller than the experimental group. The expression of proliferating cell nuclear antigen and pi67 in the xenograft tumor induced by OS cell transfection with RSK2 shRNA was significantly lower than that of the untransfected cells (Fig. 10).

\section{Discussion}

The prognosis of OS patients remains unsatisfactory despite the development and advances in the diagnosis, and treatment technology. The patients with OS often have high metastasis rate postoperatively, and chemoresistance. To explore an effective therapy method is necessary, and also a huge challenge.
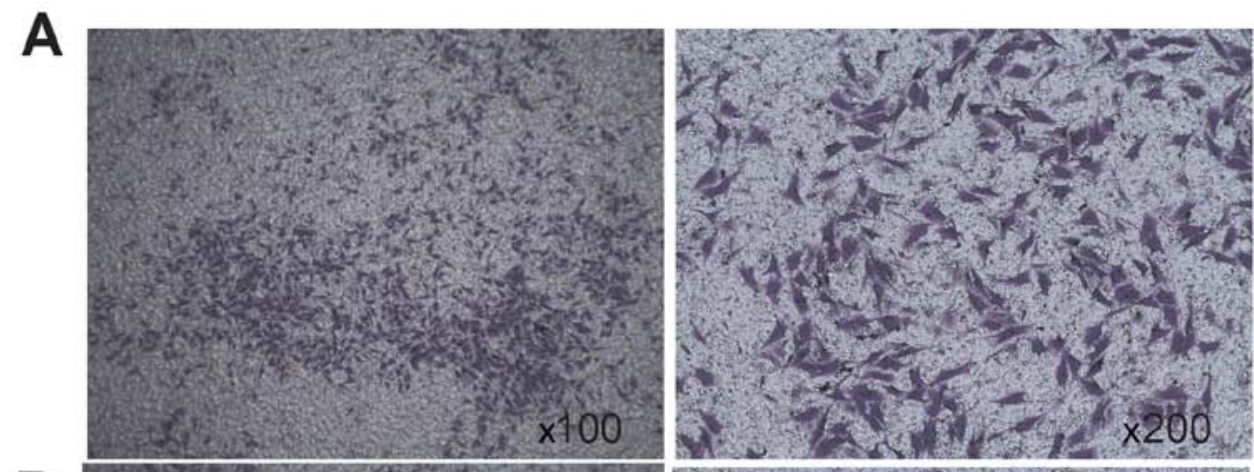

\section{Control}

B
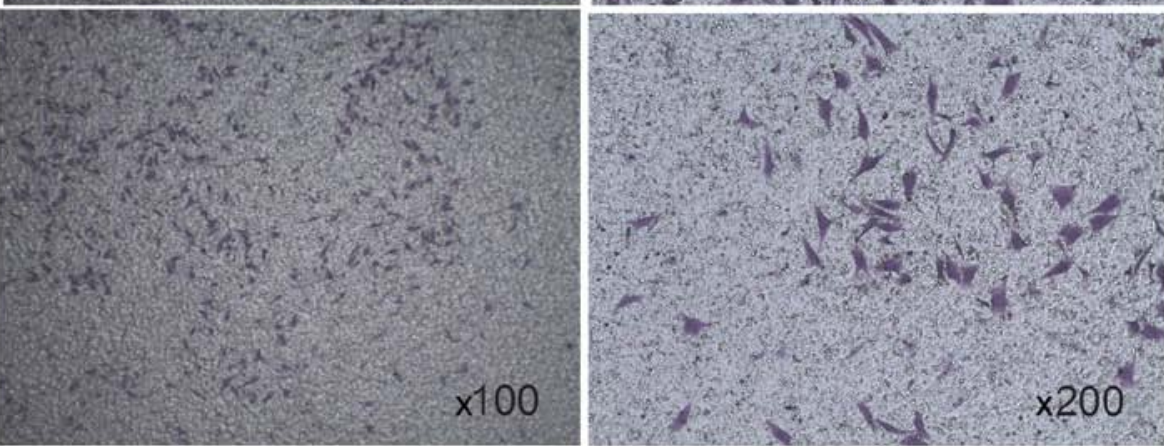

\section{RSK2 ShRNA}

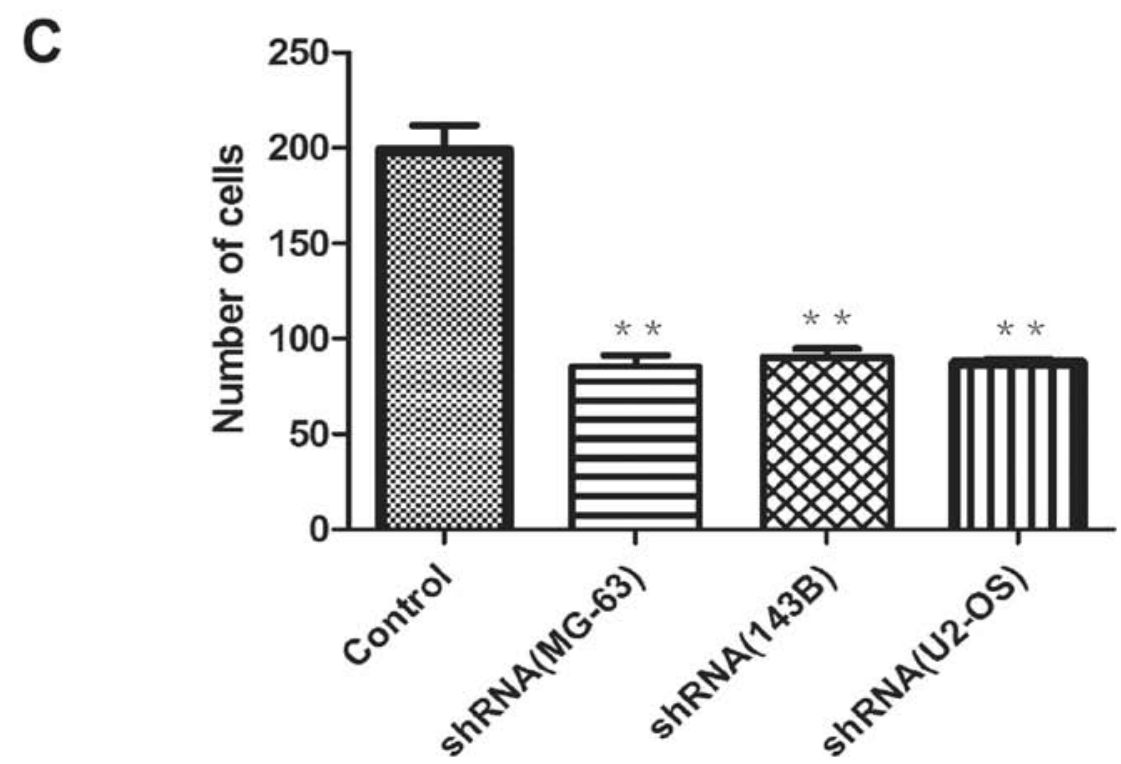

Figure 6. The ability of migration was tested by transwell chambers. (A and B) Representative images showing the cells in RSK2 shRNA groups were significantly decreased compared to the control groups by naked eye. (C) The average number of cells in 5 fields of vision. The values represent the means \pm SD of three experiments performed in triplicate. ${ }^{* *} \mathrm{P} \leq 0.01$ versus control, as determined by the Student's t-test. 
A

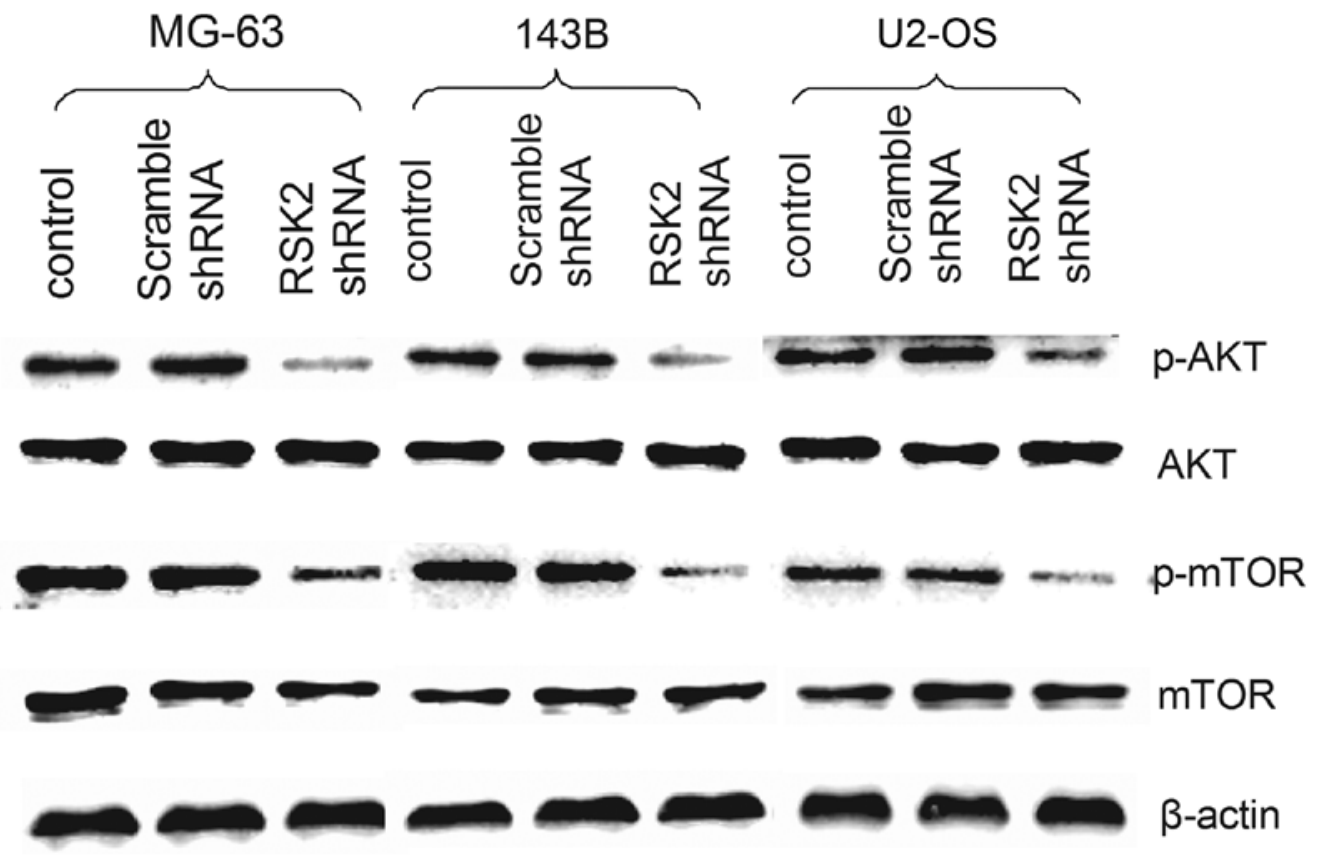

B

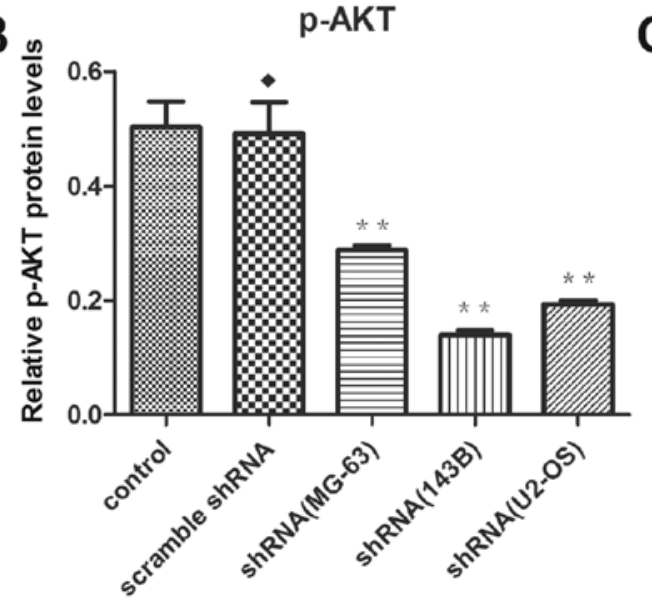

C

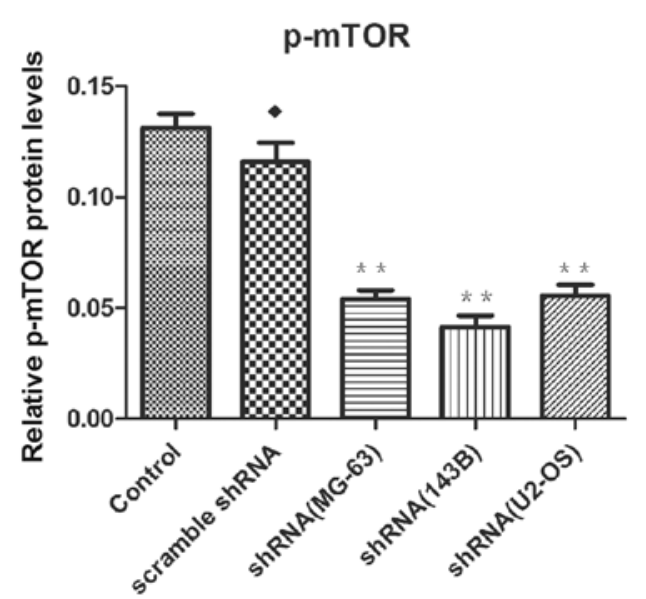

Figure 7. Phosphorylated Akt (p-Akt), Akt, mTOR and phosphorylated mTOR in OS cells detected by western blotting. (A) The amounts of phosphorylation of Akt at Thr450 and mTOR at Ser2481 are decreased after transfected with RSK2 shRNA. (B and C) The relative density of p-Akt and p-mTOR are expressed as the ratio (p-Akt/ $\beta$-actin, $p$-mTOR $/ \beta$-actin). Data represent the mean $\pm \mathrm{SD}$ of three independent experiments. ${ }^{* *} \mathrm{P} \leq 0.01$ versus control. $\bullet$, no difference versus control.

Tumorigenesis of OS is associated with biological events involved in the process of OS. Several studies have shown that RSK2 is overexpressed in prostate cancer tissues and stimulate proliferation in prostate cancer cells $(10,23)$, multiple myeloma $(12,24)$, non-small cell lung cancer (NSCLC) (25), skin cancer (26), mammary cancer (27), and in head and neck squamous cell carcinoma (28). Mutations in the human X chromosomal gene, RSK2 (RPS6KA3), cause the Coffin-Lowry syndrome (29-32).

Our study showed that median expression levels of RSK2 protein in clinical specimens collected from 30 patients with osteosarcoma were significantly elevated compared to the expression levels of para-tumor tissue and normal bone tissues. The expression was mostly located in the cell nucleus and cytoplasm, effectly supporting that RSK $1 / 2 / 3$ are present in the cytoplasm of quiescent cells, but translocate to the nucleus after stimulation (33-37). However, the result are based on a small number of samples, and a limited geographical area. More specimens need to be collected for further study.

We investigated the effects of RSK2 knockdown in OS cell lines in order to determine the potential efficacy of RSK2-targeted therapy for the treatment of OS. As the expression of RSK2 was most significantly decreased at $48 \mathrm{~h}$ after transfected with shRNA (data not shown), the difference in the viability of the three OS cell lines was detected at $48 \mathrm{~h}$ after transfection with RSK2 shRNA, as well as the other phenomena, including chemosensitivity, apoptosis and migration.

Cell viability was decreased in all OS cell lines following transfection with RSK2 shRNA. The percentage of apoptotic cells, assayed by flow cytometry, was obviously higher than the control group and the empty vector transfected group. RSK2 protein is synthesized and expressed at high levels during the G1/S-phase of the cancer cell division cycle, effectively 
A

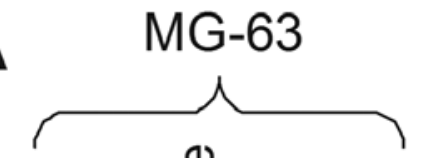

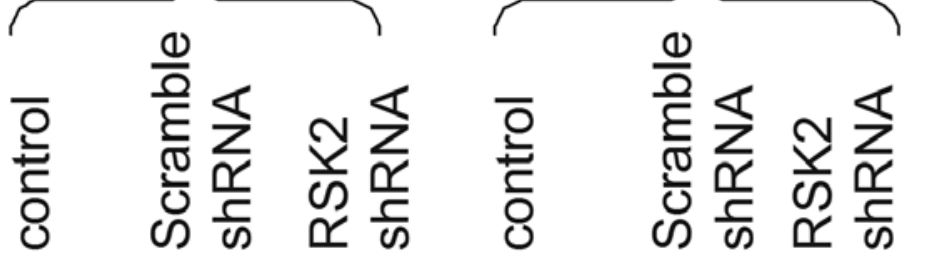
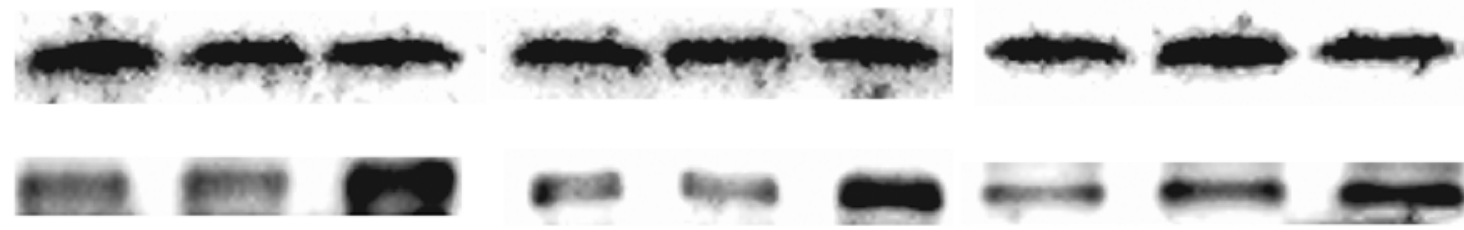

Bax
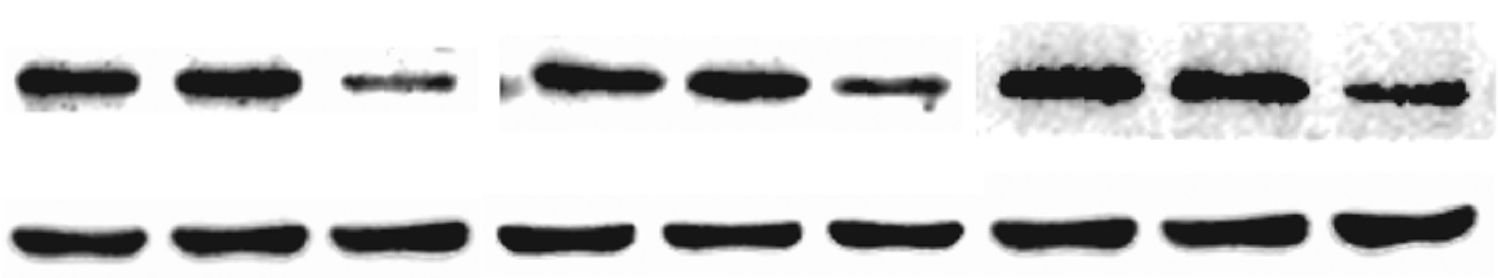

$\mathrm{Bcl} 2$
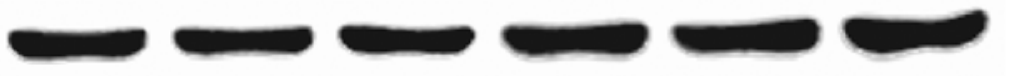

\section{$\beta$-actin}
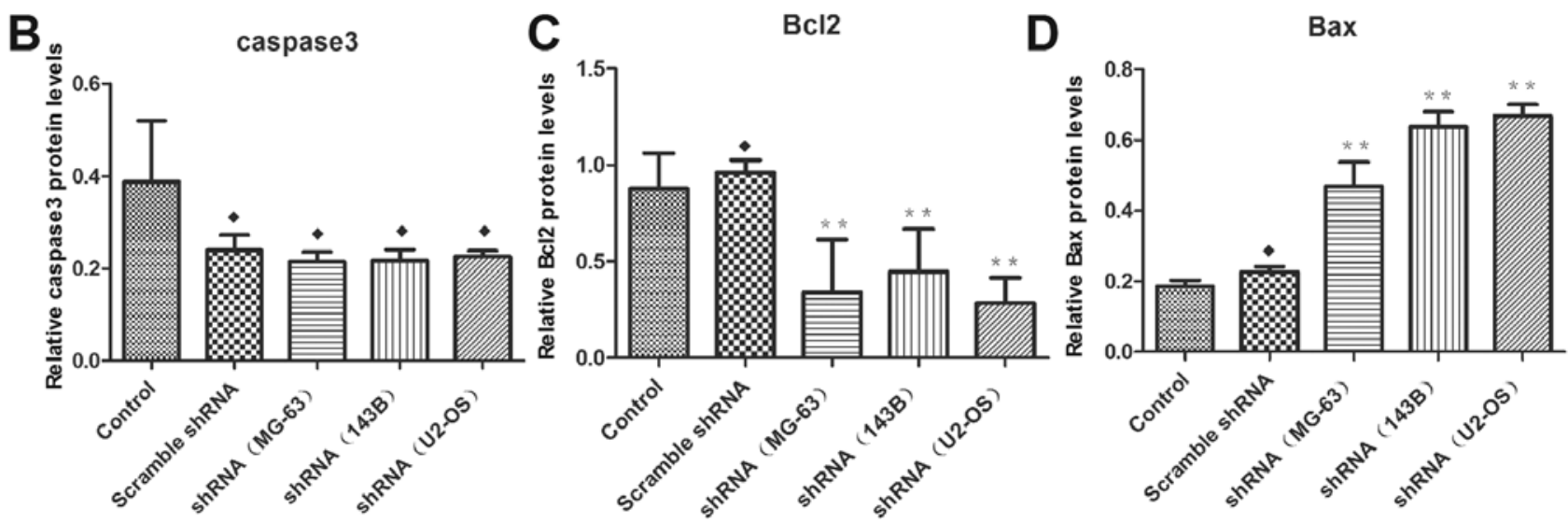

Figure 8. Caspase-3, Bax and Bcl2 in OS cells detected by western blotting. (A) The amount of Bcl2 was decreased after transfected with RSK2 shRNA. RSK2 shRNA inhibits the expression of Bax and Bcl2. The amount of caspase-3 was not changed after transfected with RSK2 shRNA. RSK2 shRNA did not inhibit the expression of caspase-3. The amounts of Bax was increased after transfected with RSK2 shRNA. RSK2 shRNA enhances the expression of Bax. (B-D) The relative density of Caspase-3, Bcl2 and Bax are expressed as the ratio (Caspase-3/ $\beta$-actin, Bcl2/ $\beta$-actin, Bax/ $/ \mathrm{B}$-actin). Data represent the mean \pm SD of three independent experiments. ${ }^{* *} \mathrm{P} \leq 0.01$ versus control. $\bullet$, no difference versus control.

supporting that the RSK2 could regulate G1 phase progression by controlling the activity of the CDK2 (cyclin-dependent kinase 2) inhibitor p27kip1 and negatively regulating GSK3, which targets c-Myc and cyclin D1 for degradation $(15,38)$.

Further study demonstrated that the expression levels of apoptosis related genes, including $\mathrm{Bax}, \mathrm{Bcl} 2$, and caspase-3, were affected by knockdown of RSK 2 by shRNA in three OS cells lines, increasing expression of Bax, reducing expression of $\mathrm{Bcl} 2$, explaining the increased apoptosis. Several groups have shown that RSK activation or overexpression inhibited cell death via inactivation of the Bcl-2 homology 3-only proapoptotic protein, Bad $(18,39,40)$. RSK2 could interact with PEA-15/PED, increased its expression and reduced apoptosis $(37,41,42)$. In our study, we suggested that inhibition of RSK2 might induce a preferential decrease in cell viability by apoptosis and delay the progressive pathological process of different types of OS cells.

After transfection with RSK2 shRNA, the sensitivity of OS cells to cisplatin and doxorubicin was increased as compared to that of control. Other groups have found that RSK2 activity was regulated by its interaction with PEA-15 and ERK, increased expression of PEA-15/PED could reduce the sensitivity of tumor cells $(37,42,43)$. RSK 2 stimulated the phosphorylation of $\mathrm{I} \kappa \mathrm{B}$ and activated the $\mathrm{NF}-\kappa \mathrm{B}$ signaling pathway $(43,44)$. Moreover, activated NF- $\kappa \mathrm{B}$ induced the production of chemoresistance genes and proteins, including P-glycoprotein and $\mathrm{ABC}$ transporters (45-47). In this study, Bcl2, downstream of NF- $\kappa \mathrm{B}$ and one of the indicators of apoptosis, was downregulated after transfected with RSK 2 shRNA, while Bax was upregulated. So we considered that the potential mechanism of 

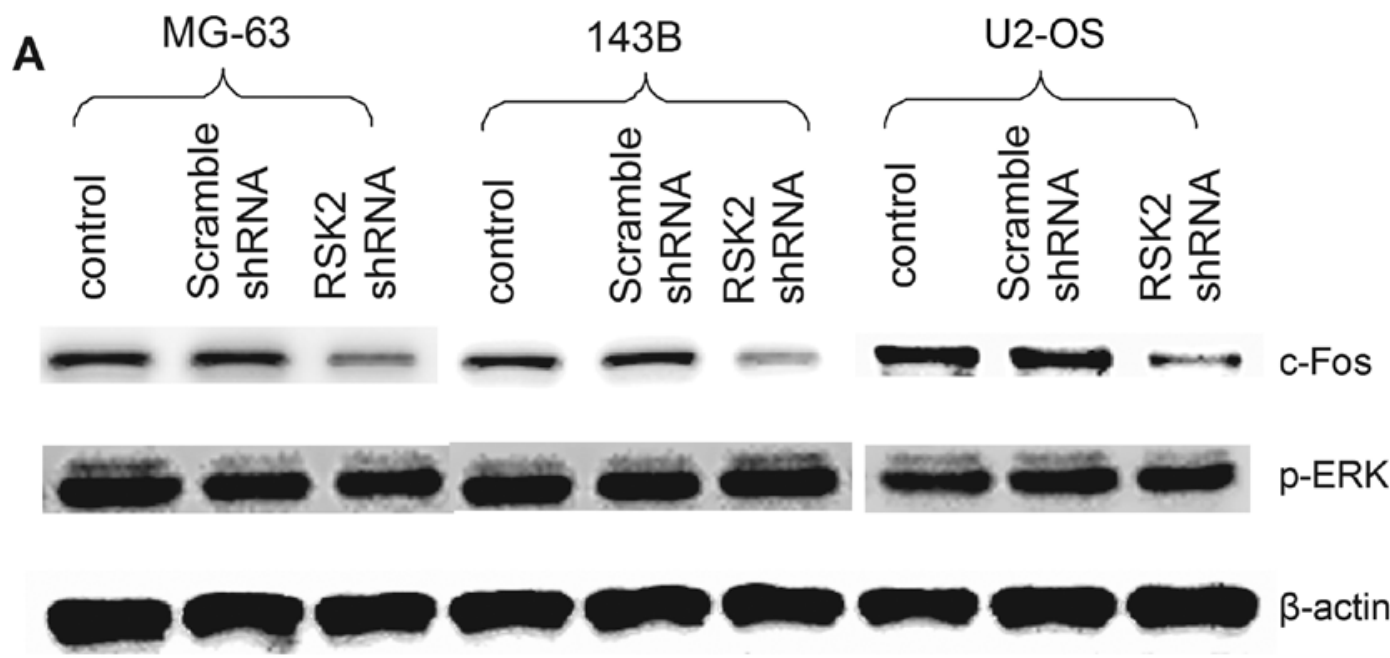

B

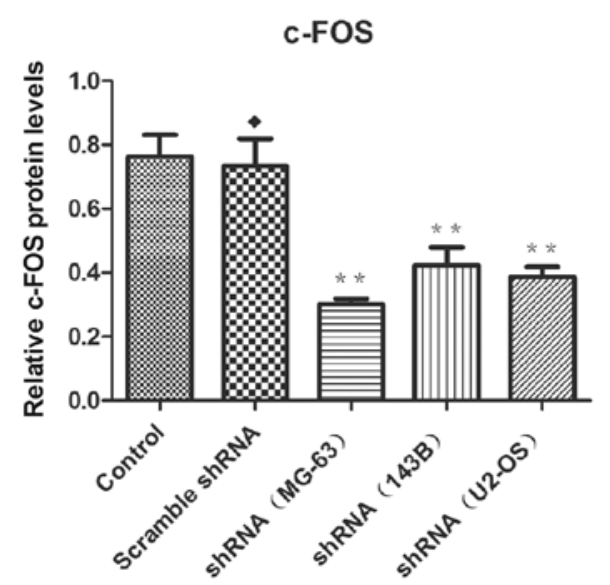

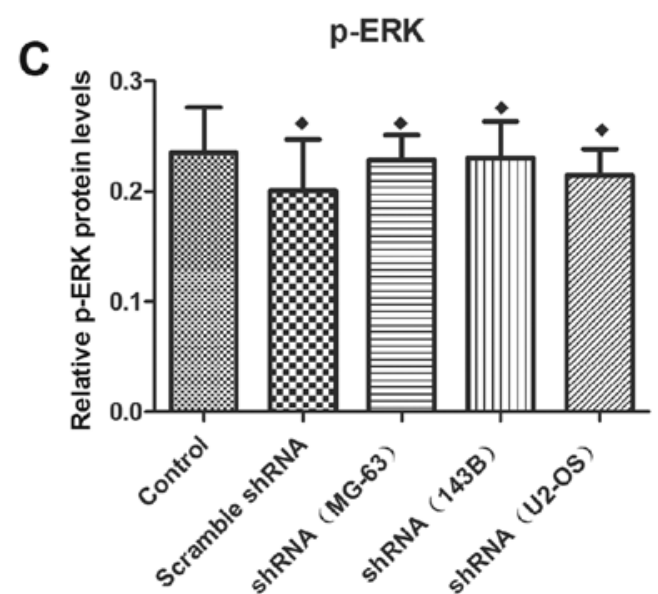

Figure 9. Phosphorylated ERK (p-ERK), and c-Fos in OS cells detected by western blotting. (A) The amount of phosphorylation of ERK at Ser473 was not changed after transfected with RSK2 shRNA. RSK2 shRNA did not inhibit phosphorylation of ERK at Ser473. The amount of c-Fos was decreased after transfected with RSK2 shRNA. RSK2 shRNA inhibited the expression of c-Fos. (B and C) The relative density of p-ERK and c-FOS are expressed as a ratio (p-ERK/ $\beta$-actin, c-Fos/ $\beta$-actin). Data represent the mean $\pm \mathrm{SD}$ of three independent experiments. ${ }^{* *} \mathrm{P} \leq 0.01$ versus control. $\bullet$, no difference versus control.

increased chemosensitivity was related with the activation of $\mathrm{NF}-\kappa \mathrm{B} / \mathrm{Bcl} 2 / \mathrm{Bax}$ pathway. Further studies, including related gene expression, related protein expression and functional assessment based on RSK2 inhibition, are required to determine the molecular mechanisms through which RSK2 affects chemosensitivity in OS cells.

Some research groups have reported that regulation of c-Fos by RSK2 was shown to play important roles in bone homoeostasis and tumorigenesis. In the absence of RSK2, c-Fos-dependent osteosarcoma formation is impaired (48). The lack of c-Fos phosphorylation leads to reduced c-Fos protein levels, which are thought to be responsible for decreased proliferation and increased apoptosis of transformed osteoblasts (49). c-Fos transgenic mice crossed with RSK2 null mice produce offspring whose tumors have increased levels of apoptosis and decreased proliferation compared to c-Fos transgenic animals expressing wild-type RSK2 (50). Interestingly, our data supported the hypothesis that RSK2 inhibition induced downregulation of c-Fos protein in OS cell lines, resulting in decreased proliferation and increased apoptosis, effectively supporting that RSK2 is essential for c-Fos transactivation because it stabilizes c-fos protein $(19,48,51)$.
It has been verified that RSK 2 could promote the expression of AKT through the increased combination with keratinocyte growth factor receptor (KGFP) on epithelial cells (52). mTOR (a downstream factor of AKT) is an essential regulator of ribosome biogenesis, mRNA translation and cell growth, and its activity is controlled by several growth-regulating pathways. Activated RSKs promotes mTOR signaling through the phosphorylation of TSC2 on Ser1798, which prevents its GAP (guanine nucleotide-activating protein) activity towards the small GTPase Rheb (53-55). More recently, RSK was shown to phosphorylate Raptor, an important mTORC1 (mTOR complex 1) scaffolding protein, providing another link between the Ras/MAPK and mTOR signaling pathways (56). In this study, inhibition with RSK2 shRNA induced downregulated expression of phosphorylated AKT and mTOR. RSK2 shRNA acted on the OS cells through AKT/mTOR signaling pathway.

PCNA and Ki67 are key controllers of multiple processes in DNA and chromatin metabolism, regulating replication, repair and chromatin assembly through interaction with a huge number of partner proteins. They exist only in proliferative cells and tumor cells and are used to detect the cell's proliferative activity. In our study, the rate of positive cells of PCNA 

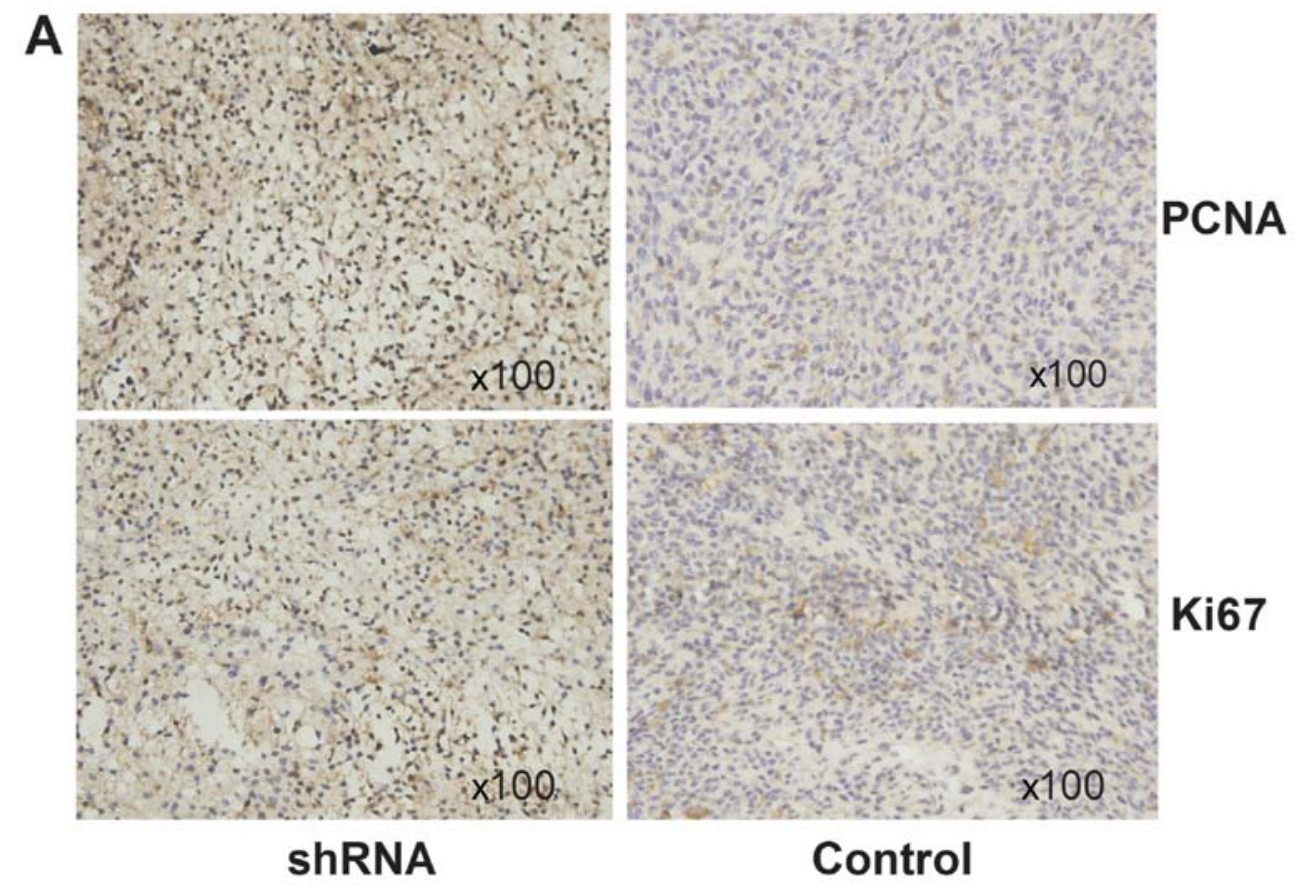

B

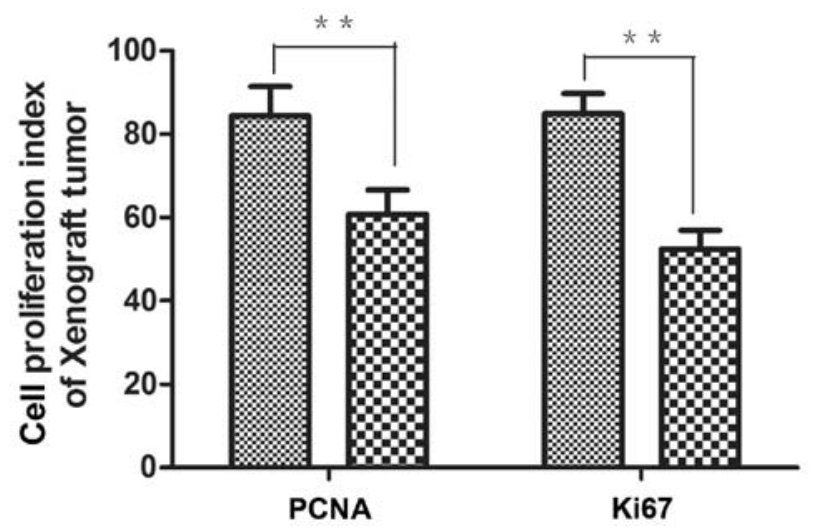

Control

$\mathbb{\infty}$ ShRNA

Figure 10. Cell proliferation index of xenograft tumors after transfection with RSK2 shRNA. (A) Representative images showing that positive cells in RSK2 shRNA groups were significantly decreased compared to the control groups by naked eye. The positive cells are brown, and the negative are blue. (B) The average number of positive cells in 100 cells from random 10 fields of vision. The values represent the means $\pm \mathrm{SD}$. ** $\mathrm{P} \leq 0.01$, as determined by the Student's t-test.

and Ki67 in xenografted tumors induced by untransfected cells are obviously higher than in the transfected groups. This verified that knockdown of RSK2 inhibited the proliferation of OS cells in nude mice.

There are now three different potent and highly specific inhibitors of RSK2 (BI-D1870, SL0101, FMK) (57). However, we did not study their effects on OS cells. Further studies are required to verify whether RSK2 inhibitors may be effective for all types of OS and whether there are side effects of RSK2 inhibitors in vivo.

In conclusion, this study demonstrated that inhibition of RSK2 decreased cell viability through the induction of apoptosis, blocked the cell cycle progress, enhanced chemosensitivity, and weakened migration in OS cell lines. These findings suggested that RSK2 may partially support cell survival and maintain the aggressive biological behavior in OS. Therefore, RSK2 may be an effective target for novel therapeutics or combination therapies with conventional anticancer drugs for OS. Further studies are required to fully elucidate the mechanism of RSK2 in OS, and to verify whether RSK2 plays a role in vivo.

\section{Acknowledgements}

We would like to acknowledge the service provided by Chongqing Key Laboratory of Molecular Oncology and Epigenetics. We thank Prof. Zhen-Ming Hu for guidance in the whole progress of experiments.

\section{References}

1. Ottaviani G and Jaffe N: The epidemiology of osteosarcoma. Cancer Treat Res 152: 3-13, 2009.

2. Sztán M,Pápai Z, Szendrôi M, Looij M and Oláh E: Allelic losses from chromosome 17 in human osteosarcomas. Pathol Oncol Res 3: $115-120,1997$.

3. Dahlin DC: Pathology of osteosarcoma. Clin Orthop Relat Res 111: 23-32, 1975. 
4. Erikson E and Maller JL: A protein kinase from Xenopus eggs specific for ribosomal protein S6. Proc Natl Acad Sci USA 82: 742-746, 1985.

5. Dalby KN, Morrice N, Caudwell FB, Avruch J and Cohen P: Identification of regulatory phosphorylation sites in mitogenactivated protein kinase (MAPK)-activated protein kinase-1a/ p90rsk that are inducible by MAPK. J Biol Chem 273: 1496-1505, 1998.

6. Frödin M, Jensen CJ, Merienne K and Gammeltoft S: A phosphoserineregulated docking site in the protein kinase RSK2 that recruits and activates PDK1. EMBO J 19: 2924-2934, 2000 .

7. Blenis J, Chung J, Erikson E, Alcorta DA and Erikson RL: Distinct mechanisms for the activation of the RSK kinases/ MAP2 kinase/pp90rsk and pp70-S6 kinase signaling systems are indicated by inhibition of protein synthesis. Cell Growth Differ 2: 279-285, 1991 .

8. Anjum R and Blenis J: The RSK family of kinases: Emerging roles in cellular signalling. Nat Rev Mol Cell Biol 9: 747-758, 2008.

9. Smith JA, Poteet-Smith CE, Xu Y, Errington TM, Hecht SM and Lannigan DA: Identification of the first specific inhibitor of p90 ribosomal S6 kinase (RSK) reveals an unexpected role for RSK in cancer cell proliferation. Cancer Res 65: 1027-1034, 2005

10. Clark DE, Errington TM, Smith JA, Frierson HF Jr, Weber MJ and Lannigan DA: The serine/threonine protein kinase, p90 ribosomal S6 kinase, is an important regulator of prostate cancer cell proliferation. Cancer Res 65: 3108-3116, 2005.

11. Cho YY, Yao K, Kim HG, Kang BS, Zheng D, Bode AM and Dong Z: Ribosomal S6 kinase 2 is a key regulator in tumor promoter induced cell transformation. Cancer Res 67: 8104-8112, 2007.

12. Kang S, Dong S, Gu TL, Guo A, Cohen MS, Lonial S, Khoury HJ, Fabbro D, Gilliland DG, Bergsagel PL, et al: FGFR3 activates RSK2 to mediate hematopoietic transformation through tyrosine phosphorylation of RSK 2 and activation of the MEK/ERK pathway. Cancer Cell 12: 201-214, 2007.

13. Woo MS, Ohta Y, Rabinovitz I, Stossel TP and Blenis J: Ribosomal S6 kinase (RSK) regulates phosphorylation of filamin A on an important regulatory site. Mol Cell Biol 24: 3025-3035, 2004.

14. Cohen P and Frame S: The renaissance of GSK3. Nat Rev Mol Cell Biol 2: 769-776, 2001.

15. Sutherland C, Leighton IA and Cohen P: Inactivation of glycogen synthase kinase-3 beta by phosphorylation: New kinase connections in insulin and growth-factor signalling. Biochem J 296 15-19, 1993.

16. Stambolic V and Woodgett JR: Mitogen inactivation of glycogen synthase kinase-3 beta in intact cells via serine 9 phosphorylation. Biochem J 303: 701-704, 1994.

17. Larrea MD, Hong F, Wander SA, da Silva TG, Helfman D, Lannigan D, Smith JA and Slingerland JM: RSK1 drives p27Kip1 phosphorylation at T198 to promote RhoA inhibition and increase cell motility. Proc Natl Acad Sci USA 106: 9268-9273, 2009.

18. Bonni A, Brunet A, West AE, Datta SR, Takasu MA and Greenberg ME: Cell survival promoted by the Ras-MAPK signaling pathway by transcription-dependent and -independent mechanisms. Science 286: 1358-1362, 1999.

19. Murphy LO, Smith S, Chen RH, Fingar DC and Blenis J: Molecular interpretation of ERK signal duration by immediate early gene products. Nat Cell Biol 4: 556-564, 2002.

20. Joel PB, Smith J, Sturgill TW, Fisher TL, Blenis J and Lannigan DA: pp90rsk1 regulates estrogen receptor-mediated transcription through phosphorylation of Ser-167. Mol Cell Biol 18: 1978-1984, 1998.

21. Yang X, Matsuda K, Bialek P, Jacquot S, Masuoka HC, Schinke T, Li L, Brancorsini S, Sassone-Corsi P, Townes TM, et al: ATF4 is a substrate of RSK2 and an essential regulator of osteoblast biology; implication for Coffin-Lowry Syndrome. Cell 117: 387-398, 2004

22. El-Haschimi K, Dufresne SD, Hirshman MF, Flier JS, Goodyear LJ and Bjørbaek C: Insulin resistance and lipodystrophy in mice lacking ribosomal S6 kinase 2. Diabetes 52: 1340-1346, 2003.

23. Burd CJ, Petre CE, Morey LM, Wang Y, Revelo MP, Haiman CA Lu S, Fenoglio-Preiser CM, Li J, Knudsen ES, et al: Cyclin D1b variant influences prostate cancer growth through aberrant androgen receptor regulation. Proc Natl Acad Sci USA 103: 2190-2195, 2006.
24. Kang S, Elf S, Dong S, Hitosugi T, Lythgoe K, Guo A, Ruan H, Lonial S, Khoury HJ, Williams IR, et al: Fibroblast growth factor receptor 3 associates with and tyrosine phosphorylates p90 RSK2, leading to RSK2 activation that mediates hematopoietic transformation. Mol Cell Biol 29: 2105-2117, 2009.

25. Dehan E, Bassermann F, Guardavaccaro D, Vasiliver-Shamis G, Cohen M, Lowes KN, Dustin M, Huang DC, Taunton J and Pagano M: betaTrCP- and Rsk1/2-mediated degradation of BimEL inhibits apoptosis. Mol Cell 33: 109-116, 2009.

26. Cho YY, Lee MH, Lee CJ, Yao K, Lee HS, Bode AM and Dong Z: RSK2 as a key regulator in human skin cancer. Carcinogenesis 33: 2529-2537, 2012

27. Czaplinska D, Turczyk L, Grudowska A, Mieszkowska M, Lipinska AD, Skladanowski AC, Zaczek AJ, Romanska HM and Sadej R: Phosphorylation of RSK2 at Tyr529 by FGFR2-p38 enhances human mammary epithelial cells migration. Biochim Biophys Acta 1843: 2461-2470, 2014.

28. Kang S, Elf S, Lythgoe K, Hitosugi T, Taunton J, Zhou W, Xiong L, Wang D, Muller S, Fan S, et al: p90 ribosomal S6 kinase 2 promotes invasion and metastasis of human head and neck squamous cell carcinoma cells. J Clin Invest 120: 1165-1177, 2010.

29. Zeniou-Meyer M, Gambino F, Ammar MR, Humeau Y and Vitale N: The Coffin-Lowry syndrome-associated protein RSK2 and neurosecretion. Cell Mol Neurobiol 30: 1401-1406, 2010.

30. Jurkiewicz D, Jezela-Stanek A, Ciara E, PiekutowskaAbramczuk D, Kugaudo M, Gajdulewicz M, Chrzanowska K, Popowska E and Krajewska-Walasek M: Four novel RSK2 mutations in females with Coffin-Lowry syndrome. Eur J Med Genet 53: 268-273, 2010.

31. Abidi F, Jacquot S, Lassiter C, Trivier E, Hanauer A and Schwartz CE: Novel mutations in Rsk-2, the gene for CoffinLowry syndrome (CLS). Eur J Hum Genet 7: 20-26, 1999.

32. Trivier E, De Cesare D, Jacquot S, Pannetier S, Zackai E, Young I, Mandel JL, Sassone-Corsi P and Hanauer A: Mutations in the kinase Rsk-2 associated with Coffin-Lowry syndrome. Nature 384: 567-570, 1996.

33. Chen RH, Sarnecki C and Blenis J: Nuclear localization and regulation of erk- and rsk-encoded protein kinases. Mol Cell Biol 12: 915-927, 1992.

34. Lenormand P, Sardet C, Pagès G, L'Allemain G, Brunet A and Pouysségur J: Growth factors induce nuclear translocation of MAP kinases (p42mapk and p44mapk) but not of their activator MAP kinase kinase (p45mapkk) in fibroblasts. J Cell Biol 122: 1079-1088, 1993.

35. Zhao Y, Bjørbaek C, Weremowicz S, Morton CC and Moller DE: RSK3 encodes a novel pp90rsk isoform with a unique N-terminal sequence: Growth factor-stimulated kinase function and nuclear translocation. Mol Cell Biol 15: 4353-4363, 1995.

36. Richards SA, Dreisbach VC, Murphy LO and Blenis J: Characterization of regulatory events associated with membrane targeting of p90 ribosomal S6 kinase 1. Mol Cell Biol 21: $7470-7480,2001$

37. Vaidyanathan $\mathrm{H}$ and Ramos JW: RSK2 activity is regulated by its interaction with PEA-15. J Biol Chem 278: 32367-32372, 2003.

38. Fujita N, Sato S and Tsuruo T: Phosphorylation of p27Kip1 at threonine 198 by p90 ribosomal protein S6 kinases promotes its binding to 14-3-3 and cytoplasmic localization. J Biol Chem 278: 49254-49260, 2003

39. Tan Y, Ruan H, Demeter MR and Comb MJ: p90 (RSK) blocks bad-mediated cell death via a protein kinase C-dependent pathway. J Biol Chem 274: 34859-34867, 1999.

40. Bertolotto C, Maulon L, Filippa N, Baier G and Auberger P: Protein kinase $\mathrm{C}$ theta and epsilon promote T-cell survival by a rsk-dependent phosphorylation and inactivation of BAD. J Biol Chem 275: 37246-37250, 2000.

41. Vaidyanathan H, Opoku-Ansah J, Pastorino S, Renganathan H, Matter ML and Ramos JW: ERK MAP kinase is targeted to RSK2 by the phosphoprotein PEA-15. Proc Natl Acad Sci USA 104: 19837-19842, 2007.

42. Formisano P, Ragno P, Pesapane A, Alfano D, Alberobello AT, Rea VE, et al: PED/PEA-15 interacts with the $67 \mathrm{kDa}$ laminin receptor and regulates cell adhesion, migration, proliferation and apoptosis. J Cell Mol Med 16: 1435-1446, 2012

43. Cude K, Wang Y, Choi HJ, Hsuan SL, Zhang H, Wang CY and Xia Z: Regulation of the G2-M cell cycle progression by the ERK5-NFkappaB signaling pathway. J Cell Biol 177: 253-264, 2007. 
44. Peng C, Cho YY, Zhu F, Xu YM, Wen W, Ma WY, Bode AM and Dong Z: RSK2 mediates NF-\{kappa\}B activity through the phosphorylation of IkappaBalpha in the TNF-R1 pathway. FASEB J 24: 3490-3499, 2010.

45. Ke SZ, Ni XY, Zhang YH, Wang YN, Wu B and Gao FG: Camptothecin and cisplatin upregulate ABCG2 and MRP2 expression by activating the $\mathrm{ATM} / \mathrm{NF}-\kappa \mathrm{B}$ pathway in lung cancer cells. Int J Oncol 42: 1289-1296, 2013.

46. Luo L, Sun YJ, Yang L, Huang S and Wu YJ: Avermectin induces P-glycoprotein expression in S2 cells via the calcium/ calmodulin/NF- $\mathrm{KB}$ pathway. Chem Biol Interact 203: 430-439, 2013.

47. Bongiovanni L, Mazzocchetti F, Malatesta D, Romanucci M, Ciccarelli A, Buracco P, De Maria R, Palmieri C, Martano M, Morello E, et al: Immunohistochemical investigation of cell cycle and apoptosis regulators (survivin, $\beta$-catenin, p53, caspase 3 ) in canine appendicular osteosarcoma. BMC Vet Res 8: 78, 2012.

48. Bakiri L, Reschke MO, Gefroh HA, Idarraga MH, Polzer K, Zenz R, Schett G and Wagner EF: Functions of Fos phosphorylation in bone homeostasis, cytokine response and tumourigenesis. Oncogene 30: 1506-1517, 2011.

49. David JP, Mehic D, Bakiri L, Schilling AF, Mandic V, Priemel M, Idarraga MH, Reschke MO, Hoffmann O, Amling M, et al: Essential role of RSK2 in c-Fos-dependent osteosarcoma development. J Clin Invest 115: 664-672, 2005.

50. Chen RH, Abate C and Blenis J: Phosphorylation of the c-Fos transrepression domain by mitogen-activated protein kinase and 90-kDa ribosomal S6 kinase. Proc Natl Acad Sci USA 90: 10952-10956, 1993.
51. Chen RH, Juo PC, Curran T and Blenis J: Phosphorylation of c-Fos at the C-terminus enhances its transforming activity. Oncogene 12: 1493-1502, 1996.

52. Pan ZZ, Devaux Y and Ray P: Ribosomal S6 kinase as a mediator of keratinocyte growth factor-induced activation of Akt in epithelial cells. Mol Biol Cell 15: 3106-3113, 2004.

53. Ma L, Chen Z, Erdjument-Bromage H, Tempst P and Pandolfi PP: Phosphorylation and functional inactivation of TSC2 by Erk implications for tuberous sclerosis and cancer pathogenesis. Cell 121: 179-193, 2005.

54. Roux PP, Ballif BA, Anjum R, Gygi SP and Blenis J: Tumorpromoting phorbol esters and activated Ras inactivate the tuberous sclerosis tumor suppressor complex via p90 ribosomal S6 kinase. Proc Natl Acad Sci USA 101: 13489-13494, 2004.

55. Rolfe M, McLeod LE, Pratt PF and Proud CG: Activation of protein synthesis in cardiomyocytes by the hypertrophic agent phenylephrine requires the activation of ERK and involves phosphorylation of tuberous sclerosis complex 2 (TSC2). Biochem J 388: 973-984, 2005.

56. Carrière A, Cargnello $M$, Julien LA, Gao H, Bonneil E, Thibault $P$ and Roux PP: Oncogenic MAPK signaling stimulates mTORC1 activity by promoting RSK-mediated raptor phosphorylation. Curr Biol 18: 1269-1277, 2008.

57. Nguyen TL: Targeting RSK: An overview of small molecule inhibitors. Anticancer Agents Med Chem 8: 710-716, 2008. 